\title{
Migotanie przedsionków u otyłego pacjenta leczonego riwaroksabanem
}

\section{Atrial fibrillation in obese patient treated with rivaroxaban}

\author{
Michał Orszulak*, Marcin Wita*, Katarzyna Mizia-Stec \\ I Katedra i Klinika Kardiologii Wydziału Lekarskiego w Katowicach, I Oddział Kardiologii, Górnośląskie Centrum Medyczne, \\ Śląski Uniwersytet Medyczny w Katowicach
}

\section{Streszczenie}

Otyły (wskaźnik masy ciała $36 \mathrm{~kg} / \mathrm{m}^{2}$ ) 47-letni mężczyzna z napadowym migotaniem przedsionków (AF) został przyjęty z powodu kolejnego, źle tolerowanego napadu AF (rytm serca do 130/min). Pacjent był leczony przewlekle riwaroksabanem w dawce $20 \mathrm{mg} /$ dobę. Ze względu na częste nawroty arytmii i jej znaczną objawowość (IV klasa wg European Heart Rhythm Association [EHRA]), a także objawy tachykardiomiopatii (frakcja wyrzutowa lewej komory 40\%), zdecydowano o wykonaniu kardiowersji i ablacji okrążającej żyły płucne. Skuteczność leczenia przeciwkrzepliwego potwierdzono w echokardiograficznym badaniu przezprzełykowym, w którymi nie uwidoczniono materiału zatorowego w uszku lewego przedsionka. Doustne antykoagulanty niebędące antagonistami witaminy $\mathrm{K}$ są bezpiecznymi i skutecznymi lekami, nawet w przypadku standardowego dawkowaniu u otyłych pacjentów.

Słowa kluczowe: migotanie przedsionków, NOAC, otyłość

Folia Cardiologica 2017; 12, 2: 200-203

\section{Wstęp}

Migotanie przedsionków (AF, atrial fibrillation) jest jednym z najczęściej rozpoznawanych zaburzeń rytmu serca. Częstości występowania w populacji oscyluje około $1 \%$. U podłoża AF leży zjawisko mikroreentry - krążenia fal pobudzeń stale natrafiających na tkankę zdolną do pobudzeń. Najlepiej poznanym ogniskiem inicjujących migotanie jest mięśniówka żył płucnych. Miejsca te są także głównym celem inwazyjnej terapii AF - izolacja żył płucnych. Najbardziej uciążliwymi powikłaniami AF pozostają powikłania zakrzepowo-zatorowe (udar niedokrwienny/przejściowy atak niedokrwienny (TIA, transient ischaemic attack)/zatorowość obwodowa), które u osób z AF występują kilkukrotnie częściej niż w populacji bez tej arytmii. Zasadne wydaje się pytanie, jak chronić pacjenta przed wyżej wymienionymi konsekwencjami. Standardem postępowania u pacjenta z AF (niezależnie od postaci: napadowej, przetrwałej czy utrwalonej), jest włączenie terapii lekami przeciwkrzepliwymi, które zmniejszają ryzyko powikłań zakrzepowo-zatorowych. Podczas kwalifikacji do terapii lekami przeciwkrzepliwymi u pacjentów z AF należy się posłużyć skalą do oceny ryzyka powikłań zakrzepowo-zatorowych ( $\mathrm{CHA}_{2} \mathrm{DS}_{2}$-VASc). Terapię doustną lekami przeciwkrzepliwymi u pacjenta można prowadzić zarówno pochodnymi warfaryny, jak i doustnymi antykoagulantami niebędącymi antagonistami witaminy K (NOAC, non-vitamin K oral antagonist anticoagulants). Preparaty warfaryny, które przez lata nie miały konkurencji, wymagają okresowej kontroli międzynarodowego wskaźnika znormalizowanego (INR, international normalized ratio) w celu weryfikacji ich skuteczności (zalecany poziom INR 2,0-3,0). Doustne antykoagulanty niebędące antagonistami witaminy K, które można stosować w niezastawkowym

*Autorzy mieli równy udział w powstałej pracy

Adres do korespondencji: lek. Michał Orszulak, I Oddział Kardiologii, Górnośląskie Centrum Medyczne im prof. L. Gieca, Śląski Uniwersytet Medyczny w Katowicach, ul Ziołowa 45/47, 40-635 Katowice; tel. 32359 88 90; faks 3225236 58; e-mail: orszul@vp.pl 
AF, nie wymagają oceny laboratoryjnej efektu ich działania, dlatego sukcesywnie zdobywają uznanie pacjentów. Poniżej przedstawiono przypadek pacjenta ilustrujący, jak skuteczne i adekwatne leczenie przeciwkrzepliwe ułatwia dalszą terapię.

\section{Przypadek kliniczny}

Mężczyzna w wieku 47 lat, z otyłością (wskaźnik masy ciała [BMI, body mass index] $36 \mathrm{~kg} / \mathrm{m}^{2}$ ) i wywiadem napadowego AF od około 3 lat został przyjęty do szpitala w ramach ostrego dyżuru kardiologicznego z powodu kolejnego napadu AF z akcją komór do 130/min. Pacjent zgłaszał napad źle tolerowanego (IV klasa wg European Heart Rhythm Association [EHRA]) AF od około 7 dni (przebywał za granicą). Był przewlekle leczony przeciwkrzepliwie riwaroksabanem w dawce $20 \mathrm{mg} /$ dobę.

W wywiadzie:

- dwukrotna kardiowersja elektryczna z powodu źle tolerowanego AF z tachyarytmią;

- zmiany przyścienne w koronarografii wykonanej w 2009 roku;

- oporne nadciśnienie tętnicze, w 2013 roku przebyty zabieg denerwacji tętnic nerkowych z wyraźną poprawą skuteczności leczenia (obecnie maksymalne ciśnienie tętnicze 150/90 mm Hg, wcześniej wartości ciśnienia skurczowego wyraźnie > 200 mm Hg mimo wielolekowej farmakoterapii);

- poszerzenie aorty wstępującej do $44 \mathrm{~mm}$;

- podejrzenie obturacyjnego bezdechu sennego

- zaburzenia gospodarki lipidowej;

- otyłość (BMI $36 \mathrm{~kg} / \mathrm{m}^{2}$ ).

Dotychczasowa farmakoterapia była następująca: chinapril w dawce 20 mg (1-0-1), doksazosyna w dawce
$4 \mathrm{mg}(0-0-1)$, betaksolol w dawce $20 \mathrm{mg}$ (1-0-0), amlodipina w dawce $10 \mathrm{mg}(0-0-1)$, hydrochlorotiazyd w dawce $12,5 \mathrm{mg}$ (1-0-0), simwastatyna w dawce $20 \mathrm{mg}(0-0-1)$, fenofibrat w dawce $267 \mathrm{mg}(1-0-0)$, riwaroksaban w dawce $20 \mathrm{mg}(1-0-0)$.

Przy przyjęciu w badaniu przedmiotowym stwierdzono AF z tachyarytmią 100-130/min (ryc. 1), ciśnienie tętnicze wynoszące 140/80 mm Hg, bez zastoju nad polami płucnymi, bez wyraźnie nasilonej duszności spoczynkowej. Wykonano przezklatkowe badanie echokardiograficzne, w którym uwidoczniono powiększenie wymiarów lewego przedsionka (LA, left atrium) (długość LA $52 \mathrm{~mm}$, powierzchnia LA $34 \mathrm{~cm}^{2}$, w poprzednim badaniu 2 miesiące wcześniej długość LA $46 \mathrm{~mm}$, powierzchnia LA $30 \mathrm{~cm}^{2}$ ), łagodna/umiarkowaną niedomykalność zastawki mitralnej, upośledzoną funkcję skurczową (EF, ejection fraction) lewej komory - 40\% (2 miesiące wcześniej EF 48-50\%), z odcinkowymi zaburzeniami kurczliwości oraz poszerzenie aorty wstępującej do $44 \mathrm{~mm}$. W badaniach laboratoryjnych nie wykazano istotnych odchyleń.

Z uwagi na częste nawroty arytmii, jej nasilone objawy, spadek EF (najprawdopodobniej w mechanizmie tachykardiomiopatii), a także postępującą dylatację LA zdecydowano o umiarowieniu arytmii i wykonaniu ablacji okrążającej żyły płucne. Pacjenta nadal poddawano adekwatnemu leczeniu przeciwkrzepliwemu (riwaroksaban), jednakże ze względu na znacznie powiększony wymiar AL oraz planowaną kardiowersję i ablację zdecydowano o wykonaniu echokardiograficznego badania przezprzełykowego, w którymi nie uwidoczniono materiału zatorowego w obrębie uszka LA.

Podjęto próbę farmakologicznej kardiowersji, podając amiodaron - bez rezultatu. Następnie wykonano kardiowersję elektryczną, uzyskując powrót rytmu zatokowego. W kolejnym dniu hospitalizacji wykonano ablację okrążającą żyły

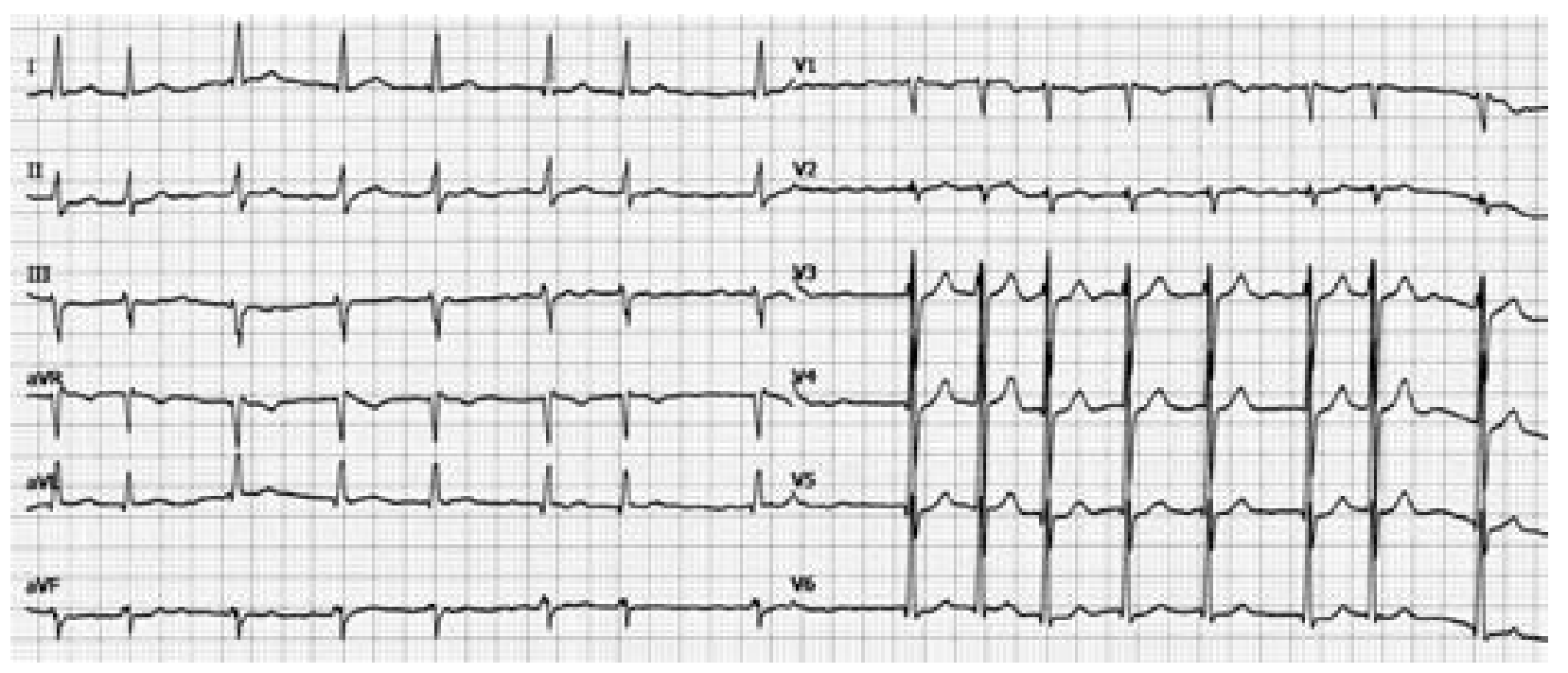

Rycina 1. Migotanie przedsionków w zapisie elektrokardiograficznym 
płucne. Z dostępu transseptalnego do LA wprowadzono elektrodę mapującą oraz ablacyjną. Wykonano mapowanie LA przy użyciu systemu elektroanatomicznego, a następnie ablację, uzyskując izolację żył płucnych. Na koniec zabiegu potwierdzono izolację elektryczną wszystkich 4 żył płucnych. Zabieg przebiegł bez powikłań.

Z powodu wysokiego ryzyka powikłań zakrzepowo-zatorowych (3 pkt. w $\mathrm{CHA}_{2} \mathrm{DS}_{2}$-VASc) zdecydowano o kontynuacji dotychczasowego leczenia przeciwkrzepliwego riwaroksabanem. Pacjentowi zalecono pilną konsultację w poradni chorób metabolicznych i otyłości oraz zmodyfikowano farmakoterapię - włączono amiodaron (początkowo w dawkach nasycających) oraz spironolakton.

\section{Wnioski}

Doustne antykoagulanty niebędące antagonistami witaminy $\mathrm{K}$ otworzyły nową erę w profilaktyce i leczeniu powikłań zakrzepowo-zatorowych. Są stosowane coraz powszechniej u chorych z AF, co ukazuje między innymi rejestr GARFIELD-AF [1]. Początkowo stosowano je wyłącznie w stabilnym okresie AF w ramach prewencji udaru mózgu. Kolejne badania spowodowały, że stopniowo dopuszczano do stosowania NOAC w innych sytuacjach, takich jak kardiowersja elektryczna [2] czy ablacja [3]. Zapewne pozostaje kwestią czasu, kiedy wskazania do stosowania NOAC zostaną rozszerzone jeszcze bardziej - do prewencji wtórnej udaru mózgu, zastawkowego AF.

$\mathrm{U}$ opisanego pacjenta wynik w $\mathrm{CHA}_{2} \mathrm{DS}_{2}$-VASc wynosi 3 punkty (nadciśnienie tętnicze, choroba naczyniowa, niewydolność serca), zatem roczne ryzyko udaru to około 3,2\% [4]. Pacjent ten powinien stosować przewlekle leczenie przeciwkrzepliwe. NOAC stanowią ułatwienie zarówno dla chorego jak i lekarza. Są nie gorsze w zapobieganiu powikłaniom udarowym i skuteczniejsze w zakresie redukcji krwawień.

Nierozstrzygniętym problemem pozostaje dawkowanie NOAC w zależności od wagi ciała. Jedynie w przypadku apiksabanu konieczna jest zmniejszenie dawki przy wadze nie większej niż 60 kg w połączeniu z niewydolnością nerek [5]. Brakuje doświadczeń w przypadku chorych z nadwaga/otyłością, a stanowią oni coraz większy odsetek populacji. W dotychczasowych randomizowanych badaniach stanowili oni niewielki odsetek chorych i nie ustalono jednoznacznie standardów postępowania w tej grupie chorych. Güler i wsp. [6] jedynie na pojedynczych przypadkach przeanalizowali dane dotyczące skuteczności NOAC wśród otyłych pacjentów. Problem ten może szczególne dotyczyć riwaroksabanu, którego biodostępność istotnie zmniejsza się w przypadku przyjmowania leku razem z posiłkiem. Ocenę skuteczności leczenia przeciwkrzepliwego utrudnia fakt braku laboratoryjnych oznaczeń oceny efektu przeciwkrzepliwego NOAC.

Opierając się na subanalizie badania J-ROCKET AF [7] (jednakowa skuteczność riwaroksabanu niezależnie od wartości BMI) oraz biorąc pod uwage fakt, że dotychczasowa terapia przeciwkrzepliwa była skuteczna (brak materiału zatorowego w badaniu przezprzełykowym), zdecydowaliśmy się na kontynuowanie leczenia riwaroksabanem w dawce $20 \mathrm{mg} /$ dobę.

\section{Podsumowanie}

W metaanalizach przeprowadzonych dotychczas badań potwierdzono wysoką skuteczność i bezpieczeństwo NOAC.

\section{Konflikt interesów}

Brak.

\section{Abstract}

A 47-year-old, obese man (body mass index $36 \mathrm{~kg} / \mathrm{m}^{2}$ ), with paroxysmal atrial fibrillation (AF), was admitted to hospital because of poorly tolerated recurrence of AF episode (heart rate $130 \mathrm{bpm}$ ). Patient was chronically treated with rivaroxaban $20 \mathrm{mg}$ qd. Due to often recurrence of arrhythmia, extremely badly tolerated (European Heart Rhythm Association [EHRA] IV) together with signs of tachycardia-induced cardiomyopathy (left ventricular ejection fraction 40\%) restoration of sinus rhythm and radiofrequency ablation (circumferential pulmonary vein isolation) were performed. Before procedures, efficacy of anticoagulation treatment was proved by transesophageal echocardiogram revealing no cloth in left atrial appendage. Non-vitamin $\mathrm{K}$ oral antagonist anticoagulants are safe and effective medications, even with standard dosing in obese patients.

Key words: atrial fibrillation, NOAC, obesity

Folia Cardiologica 2017; 12, 2: 200-203 


\section{Piśmiennictwo}

1. Stępińska J, Kremis E, Konopka A, et al. Stroke prevention in atrial fibrillation patients in Poland and other European countries: insights from the GARFIELD-AF registry. Kardiol Pol. 2016; 74(4): 362-371, doi: 10.5603/KP.a2015.0173, indexed in Pubmed: 26365937.

2. Hohnloser SH, Cappato R, Ezekowitz MD, et al. X-VeRT Steering Committee and Investigators, $X$-VeRT Investigators. Rivaroxaban vs. vita$\min \mathrm{K}$ antagonists for cardioversion in atrial fibrillation. Eur Heart J. 2014; 35(47): 3346-3355, doi: 10.1093/eurheartj/ehu367, indexed in Pubmed: 25182247.

3. Calkins H, Gerstenfeld EP, Schilling R, et al. RE-CIRCUIT Study Steering Committee. RE-CIRCUIT study-randomized evaluation of Dabigatran etexilate compared to warfarin in pulmonary vein ablation: assessment of an uninterrupted periprocedural anticoagulation strategy. Am J Cardiol. 2015; 115(1): 154-155, doi: 10.1016/j.amjcard.2014.10.002, indexed in Pubmed: 25456859.

4. Camm AJ, Lip GYH, De Caterina R, et al. ESC Committee for Practice Guidelines-CPG, Document Reviewers, ESC Committee for Practice
Guidelines (CPG). 2012 focused update of the ESC Guidelines for the management of atrial fibrillation: an update of the 2010 ESC Guidelines for the management of atrial fibrillation. Developed with the special contribution of the European Heart Rhythm Association. Europace. 2012; 14(10): 1385-1413, doi: 10.1093/europace/eus305, indexed in Pubmed: 22923145.

5. Heidbuchel H, Verhamme P, Alings M, et al. Advisors:, European Heart Rhythm Association. European Heart Rhythm Association Practical Guide on the use of new oral anticoagulants in patients with non-valvular atrial fibrillation. Europace. 2013; 15(5): 625-651, doi: 10.1093/ europace/eut083, indexed in Pubmed: 23625942.

6. Güler E, Babur Güler G, Demir GG, et al. A review of the fixed dose use of new oral anticoagulants in obese patients: Is it really enough? Anatol J Cardiol. 2015; 15(12): 1020-1029, doi: 10.5152/AnatolJCardiol.2015.6532, indexed in Pubmed: 26663225.

7. Delgado-Fernández M. The J-ROCKET AF study: a matter of ethnicity or a matter of weight? Circ J. 2013; 77(10): 2636, indexed in Pubmed: 23903064. 